\title{
A new western Atlantic snapping shrimp of the Alpheus macrocheles group (Caridea, Alpheidae) revealed by morphological, molecular and color data
}

\author{
Guidomar O. SOLEDADE ${ }^{1}$, Mariana TEROSSI ${ }^{2}$, Justin A. SCIOLI ${ }^{3}$, \\ Fernando Luis MANTELATTO ${ }^{4} \&$ Alexandre O. ALMEIDA ${ }^{5}$ \\ ${ }^{1,5}$ Laboratory of Crustacean Biology, Department of Zoology, Biosciences Center, \\ Federal University of Pernambuco (UFPE), Recife, Pernambuco, Brazil. \\ ${ }^{2}$ Laboratory of Carcinology, Department of Zoology, Institute of Biosciences, Federal University of \\ Rio Grande do Sul (UFRGS), Porto Alegre, Rio Grande do Sul, Brazil. \\ ${ }^{3}$ Department of Biology, University of Louisiana (ULL), Lafayette, USA. \\ ${ }^{4}$ Laboratory of Bioecology and Crustacean Systematics (LBSC), Department of Biology, \\ Faculty of Philosophy, Science and Letters at Ribeirão Preto (FFCLRP), \\ University of São Paulo (USP), Ribeirão Preto, São Paulo, Brazil. \\ ${ }^{*}$ Corresponding author: guidoosoledade@gmail.com \\ ${ }^{2}$ Email: mterossirm@gmail.com \\ 32Email: justinscioli@gmail.com \\ [4Email: flmantel@usp.br \\ ${ }^{5}$ Email: aoalmeida.ufpe@gmail.com

\footnotetext{
${ }^{1}$ urn:1sid:zoobank.org:author:F44DCD54-0B7B-4CE2-B71A-0197DFA90AE4

${ }^{2}$ urn:lsid:zoobank.org:author:BF8162AA-8C9C-42DD-81D9-4F9D3921C8EC

${ }^{3}$ urn:1sid:zoobank.org:author:B224470E-6BE8-4F28-BB1D-1590783C0A17

${ }^{4}$ urn:Isid:zoobank.org:author:7B129B95-A42A-4381-A9FC-7921E095923E

${ }^{5}$ urn:1sid:zoobank.org:author:A33D9B41-EAA0-4E1E-8493-BD76266F7F34
}

\begin{abstract}
Alpheus macrocheles (Hailstone, 1835), a species originally described from the northeastern Atlantic, has been reported from Brazil based on material from the north and northeast coasts and Espírito Santo. However, a thorough morphological comparison between Brazilian material reported as A. macrocheles and eastern Atlantic material of A. macrocheles revealed consistent differences, suggesting that the Brazilian specimens belong to an undescribed species. Alpheus ramosportoae sp. nov. is therefore now described based on material from Amapá to Pernambuco, Brazil. Morphological differences between the new species and A. macrocheles s. str. were supported by the clear divergence of 16S rRNA gene sequences (18\% of genetic distance), separating the species in two distinct clades. Differences in the color pattern also were observed and illustrated.
\end{abstract}

Keywords. Alpheid, new species, South-West Atlantic, Brazil, 16S. 
Soledade G.O., Terossi M., Scioli J.A., Mantelatto F.L. \& Almeida A.O. 2019. A new western Atlantic snapping shrimp of the Alpheus macrocheles group (Caridea, Alpheidae) revealed by morphological, molecular and color data. European Journal of Taxonomy 581: 1-21. https://doi.org/10.5852/ejt.2019.581

\section{Introduction}

The highly diverse genus Alpheus Fabricius, 1798, currently with 313 valid species throughout the world (e.g., De Grave \& Fransen 2011; Anker 2012; Komai \& Ohtomi 2018; Dehghani et al. 2019), was subdivided into seven informal morphological groups by Coutière $(1897,1905)$. This infrageneric division was continued in several subsequent major taxonomic works (Banner 1953; Crosnier \& Forest 1966; Kim \& Abele 1988). However, preliminary molecular data suggested that some of these morphological groups may not be monophyletic (Williams et al. 2001). In addition, molecular evidence has demonstrated that many species of Alpheus are in fact species complexes (e.g., Williams et al. 2001; Anker et al. 2006; Mathews \& Anker 2009), many of which have been resolved by integrative taxonomy (e.g., Anker et al. 2009; Almeida et al. 2014; Bracken-Grissom et al. 2014). Despite these numerous revisions, many unresolved taxonomic issues still persist in Alpheus, good examples being the large pantropical $A$. paracrinitus Miers, 1881 species complex, or the speciose American A. packardii Kingsley, 1880 species complex (Williams et al. 2001).

The species of the Alpheus macrocheles (Hailstone, 1835) species group (sensu Coutière 1905) are characterized by a diagnostic major cheliped morphology, with the chela strongly twisted and compressed, and the plane of dactylar articulation deviating from the plane perpendicular to the dorsal margin, often resulting in a pair of distinct grooves on the lateral face of the chela. Based on this typical morphology, the group currently includes 33 valid species distributed worldwide. Within the A. macrocheles group, several species appear to be morphologically more or less close to A. macrocheles s. str. and have been tentatively grouped together as A. macrocheles complex (Anker \& De Grave 2012). Whether this morphologically vaguely defined complex also forms a monophyletic group remains to be shown in the broader analysis of the entire $A$. macrocheles group. Nevertheless, the A. macrocheles complex sensu Anker \& De Grave (2012) includes 10 species: A. amblyonyx Chace, 1972, A. lentiginosus Anker \& Nizinski, 2011, A. pouang Christoffersen, 1979 and A. puapeba Christoffersen, 1979 in the western Atlantic; A. cedrici Anker \& De Grave, 2012 in the central Atlantic; A. macrocheles in the eastern and central Atlantic (with questionable records from the western Atlantic, see below); A. platydactylus Coutière, 1897 in the eastern Atlantic; A. bellimanus Lockington, 1877 and A. rectus Kim \& Abele, 1988 in the eastern Pacific; and finally, A. albatrossae Banner, 1953 in the Indo-West Pacific (Anker \& De Grave 2012).

The type locality of A. macrocheles is off Hastings, England, in the English Channel (Hailstone 1835). Subsequently, this species has been recorded throughout the Mediterranean Sea and on both sides of the Atlantic Ocean, as well as from Ascension Island in the Central Atlantic (Holthuis 1951; Crosnier \& Forest 1966; d'Udekem d'Acoz 1999; De Grave et al. 2017). In Brazil, the species has been recorded from several localities, ranging from Amapá to Espírito Santo (see Soledade \& Almeida 2013 for records). However, the true identity of records of $A$. macrocheles on the Brazilian coast is uncertain for the following main reasons: many records of $A$. macrocheles from Brazil lack detailed morphological information or illustrations and, unfortunately, specimens associated with these records were not always deposited in zoological collections, making confirmation of their identity impossible (Anker \& De Grave 2012; Soledade \& Almeida 2013). Exceptionally, Ramos-Porto (1979) provided a detailed morphological account and good illustrations of the Brazilian material of A. macrocheles, showing that specimens examined by her were in fact not A. amblyonyx. The material used by Ramos-Porto (1979) was deposited in the carcinological collection of the Universidade Federal de Pernambuco in Recife (UFPE), which is currently integrated in the collections of the Museu de Oceanografia Professor Petrônio Alves 
Coelho, Universidade Federal de Pernambuco (MOUFPE). Additional fresh specimens of the Brazilian A. macrocheles were collected during two expeditions carried out off Recife, Pernambuco, northeastern Brazil, in 2018. This material was collected by dredges between 50 and $65 \mathrm{~m}$, on mud, sand, calcareous algae and fragmented coral rubble.

While examining a series of specimens identified as A. macrocheles from northeastern Brazil deposited in the MOUFPE collection, including the Ramos-Porto (1979) specimens, we observed subtle morphological differences between them and the eastern Atlantic material of $A$. macrocheles. These differences were corroborated by DNA sequencing of the freshly collected material and also by slight differences in the color patterns between the two forms. In the present study, we describe a new species of Alpheus from the Brazilian coast, putatively closely related to A. macrocheles based on the combined morphological and molecular datasets.

\section{Material and methods}

Specimens examined in this study remain deposited in the following institutions:

CCDB $=$ Coleção de Crustáceos do Departamento de Biologia da Faculdade de Filosofia, Ciências e Letras de Ribeirão Preto, Ribeirão Preto, Brazil

MNHN $=$ Muséum national d'histoire naturelle, Paris, France

MNRJ $\quad=$ Museu Nacional, Universidade Federal do Rio de Janeiro, Rio de Janeiro, Brazil

MOUFPE $=$ Museu de Oceanografia Professor Petrônio Alves Coelho, Universidade Federal de Pernambuco, Recife, Brazil

MZUSP $\quad=$ Museu de Zoologia, Universidade de São Paulo, São Paulo, Brazil

RMNH $\quad=$ Naturalis Biodiversity Center, Leiden, The Netherlands

UNAM-CNCR $=$ Colección Nacional de Crustáceos, Universidad Nacional Autónoma de México, Ciudad de México, Mexico

We carried out a detailed morphological analysis of 48 specimens (A. macrocheles Brazil vs East Atlantic) compared to three specimens of A. amblyonyx (Caribbean Sea) using 42 characters photographed through a stereo microscope with an image capture system. Illustrations were generated from these images through vectorization in the Adobe Illustrator ${ }^{\circledR}$ program (Coleman 2003, 2009). This analysis yielded a set of characters useful for species distinction that were used in the morphological comparisons carried out in the Discussion section.

For the phylogenetic analysis of $A$. macrocheles Brazil vs East Atlantic, we used a combination of original molecular sequence data (e.g., for the new species) and sequence data retrieved from GenBank (Table 1). Whole genomic DNA was extracted from pleon tissue using the Qiagen DNeasy ${ }^{\circledR}$ Blood and Tissue Kit (Cat. No. 69504) following the manufacturer's instructions. A $\sim 550$ base pair region of the $16 \mathrm{~S}$ small ribosomal subunit gene was amplified from the extracted DNA through PCR (Polymerase Chain Reaction) (Sambrook et al. 1989) using the primers: 1472 (5'-AGATAGAAACCAACCTGG-3') and 16SL2 (5'-TGCCTGTTTATCAAAAACAT-3') (Crandall \& Fitzpatrick 1996; Schubart et al. 2002). PCR reactions were done according to the protocol of Mantelatto et al. $(2009,2018)$, in $25 \mu$ l volumes containing $5 \mathrm{M}$ betaine, 10X PCR buffer, primers, $25 \mathrm{mM} \mathrm{MgCl}_{2}, 200 \mu \mathrm{M}$ dNTPs, deionized water, 1 unit Taq polymerase and $2 \mu 1$ of extracted genomic DNA, and reactions were performed in a Veriti 96Well Thermal Cycler ${ }^{\circledR}$ (Applied Biosystems) with specific thermal cycles for the utilized set of primers (melting temperature of $48^{\circ} \mathrm{C}$ ). PCR products were visualized using gel electrophoresis with $1 \%$ agarose gel on a Transilluminator. PCR products were purified using the Exo-sap ${ }^{\circledR}$ Purification Kit following the manufacturer's instructions. Cycle sequencing reactions were performed in $20 \mu \mathrm{l}$ volumes using Big Dye ${ }^{\circledR}$ Terminator ver. 3.1 Cycle Sequencing Kit (Applied Biosystems) following the manufacturer's instructions. Sequencing was performed on an ABI 3100 Genetic Analyzers ${ }^{\circledR}$ at the ACTGENE - Análises 
Table 1. List of specimens used in genetic analysis. Abbreviations: $\mathrm{CCDB}=$ Coleção de Crustáceos do Departamento de Biologia da Faculdade de Filosofia, Ciências e Letras de Ribeirão Preto, Ribeirão Preto, Brazil; MNHN = Muséum national d'histoire naturelle, Paris, France; MNRJ = Museu Nacional, Universidade Federal do Rio de Janeiro, Rio de Janeiro, Brazil; MOUFPE = Museu de Oceanografia Professor Petrônio Alves Coelho, Universidade Federal de Pernambuco, Recife, Brazil; MZUSP = Museu de Zoologia, Universidade de São Paulo, São Paulo, Brazil; OUMNH = Oxford University Museum of Natural History, United Kingdom; RMNH = Naturalis Biodiversity Center, Leiden, The Netherlands; UF = Florida Museum of Natural History, USA; ULLZ = University of Louisiana, Lafayette Zoological Collection, USA; UNAM-CNCR = Colección Nacional de Crustáceos, Universidad Nacional Autónoma de México, Ciudad de México, Mexico.

\begin{tabular}{|c|c|c|c|c|}
\hline Taxon & Locality & $\begin{array}{l}\text { Catalogue } \\
\text { number }\end{array}$ & GenBank & Reference \\
\hline Alpheus amblyonyx Chace, 1972 & $\begin{array}{l}\text { Mexico (Gulf of } \\
\text { Mexico) }\end{array}$ & ULLZ 6615 & MK714200 & $\begin{array}{l}\text { Soledade et al. } \\
\text { (2019) }\end{array}$ \\
\hline Alpheus amblyonyx & $\begin{array}{l}\text { Quintana Roo, } \\
\text { Mexico }\end{array}$ & $\begin{array}{l}\text { UNAM-CNCR } \\
21271\end{array}$ & MK714201 & $\begin{array}{l}\text { Soledade et al. } \\
\qquad \text { (2019) }\end{array}$ \\
\hline Alpheus amblyonyx & Belize & ULLZ 16584 & MK714202 & $\begin{array}{l}\text { Soledade et al. } \\
\text { (2019) }\end{array}$ \\
\hline Alpheus amblyonyx & Guadeloupe & MNHN 12026 & MK714203 & $\begin{array}{l}\text { Soledade et al. } \\
\qquad \text { (2019) }\end{array}$ \\
\hline Alpheus amblyonyx & French Antilles & UF 32400 & MK714204 & $\begin{array}{l}\text { Soledade et al. } \\
\text { (2019) }\end{array}$ \\
\hline Alpheus crockeri (Armstrong, 1941) & Cape Verde & $\begin{array}{c}\text { OUMNH } \\
2014-01-00330\end{array}$ & MK714205 & $\begin{array}{l}\text { Soledade et al. } \\
\qquad \text { (2019) }\end{array}$ \\
\hline $\begin{array}{l}\text { Alpheus macrocheles (Hailstone, } \\
\text { 1835) }\end{array}$ & Azores, Portugal & RMNH 51342 & MK714206 & $\begin{array}{l}\text { Soledade et al. } \\
\text { (2019) }\end{array}$ \\
\hline Alpheus macrocheles & Azores, Portugal & $\begin{array}{c}\text { OUMNH } \\
2002-09-0003\end{array}$ & MK714208 & $\begin{array}{l}\text { Soledade et al. } \\
\qquad \text { (2019) }\end{array}$ \\
\hline Alpheus macrocheles & $\begin{array}{l}\text { Canary Islands, } \\
\text { Spain }\end{array}$ & RMNH 51363 & MK714207 & $\begin{array}{l}\text { Soledade et al. } \\
\qquad \text { (2019) }\end{array}$ \\
\hline Alpheus puapeba Christoffersen, 1979 & $\begin{array}{l}\text { Rio de Janeiro, } \\
\text { Brazil }\end{array}$ & MNRJ 21836 & MK714209 & $\begin{array}{l}\text { Soledade et al. } \\
\text { (2019) }\end{array}$ \\
\hline Alpheus ramosportoae sp. nov. & off Ceará, Brazil & MOUFPE 13703 & MK918615 & Present study \\
\hline Alpheus ramosportoae sp. nov. & $\begin{array}{l}\text { off Recife, } \\
\text { Brazil }\end{array}$ & MOUFPE 19470 & MK918616 & Present study \\
\hline Alpheus ramosportoae sp. nov. & $\begin{array}{l}\text { off Recife, } \\
\text { Brazil }\end{array}$ & MZUSP 39146 & MK918617 & Present study \\
\hline Alpheus ramosportoae sp. nov. & $\begin{array}{l}\text { off Recife, } \\
\text { Brazil }\end{array}$ & CCDB 6120 & MK918618 & Present study \\
\hline $\begin{array}{l}\text { Synalpheus cf. brevicarpus Herrick, } \\
1891\end{array}$ & $\begin{array}{l}\text { Ubatuba, São } \\
\text { Paulo, Brazil }\end{array}$ & CCDB 3419 & KF667548 & $\begin{array}{l}\text { Almeida et al. } \\
\text { (2014) }\end{array}$ \\
\hline $\begin{array}{l}\text { Synalpheus fritzmuelleri Coutière, } \\
1909\end{array}$ & Gulf of Mexico & ULLZ 7136 & EU868642 & $\begin{array}{l}\text { Bracken et al. } \\
\quad \text { (2009) }\end{array}$ \\
\hline
\end{tabular}


Moleculares Ltda - ME, Porto Alegre, Brazil. Sequences were confirmed by sequencing both forward and reverse strands. Sequence assembly was performed using the program Bioedit ver. 7.0.9.0 (Hall 2005). Sequences were aligned using MUSCLE (Edgar 2004), with default parameters, on the platform Cyberinfrastructure for Phylogenetic Research (CIPRES) (Miller et al. 2010).

Initially, an analysis was performed using jModelTest (Darriba et al. 2012), implemented on CIPRES, to find out which substitution model best fits the data, using the Bayesian Information Criterion (BIC). Bayesian inference analysis was carried out using the software MrBayes ver. 3.2.6 (Ronquist et al. 2012), implemented on CIPRES, using the optimal parameters obtained from jModelTest. In the analysis, one tree was sampled for every 1000 generations of 20000000 generations, starting with a randomly generated tree. Four independent runs were performed and the convergence of runs was analyzed using Tracer ver. 1.6 (Rambaut et al. 2014). The first $15 \%$ of trees and parameters were discarded as burn-in and a final tree was generated in Tree Annotator ver. 1.8.4 (implemented in BEAST, Drummond et al. 2012). Posterior probability values greater than $95 \%$ were reported. A genetic distance matrix was constructed in MEGA ver. 5 (Tamura et al. 2011) based on the optimal substitution model selected by jModelTest.

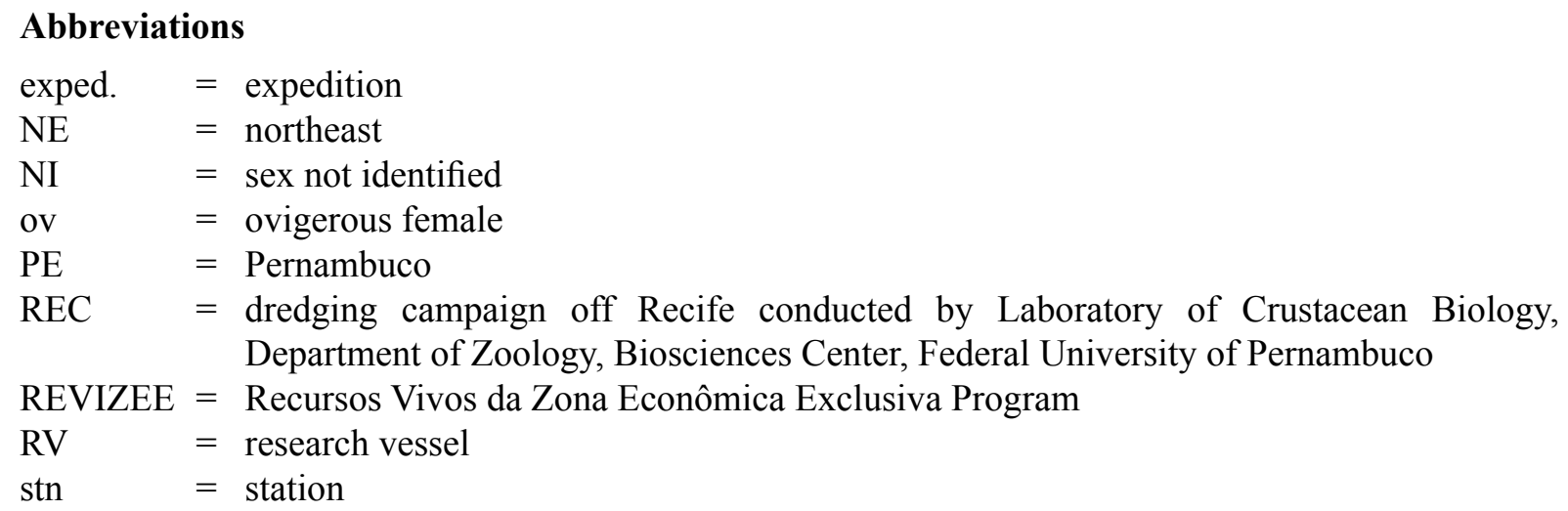

\title{
Results
}

\author{
Class Malacostraca Latreille, 1802 \\ Order Decapoda Latreille, 1802 \\ Infraorder Caridea Dana, 1852 \\ Family Alpheidae Rafinesque, 1815 \\ Genus Alpheus Fabricius, 1798
}

Alpheus ramosportoae sp. nov. urn:1sid:zoobank.org:act:B9DFFA34-24DA-4672-8A56-A474B3406B71

Figs $1-4$

Alpheus macrocheles - Ramos-Porto 1979: 118, figs. 1-6 [not Alpheus macrocheles (Hailstone, 1835)]. (?) Alpheus macrocheles - Coelho \& Ramos-Porto 1980: 135; 1995: 116 - Coelho et al. 1980: 55; 1986: 84 - Fausto Filho 1980: 113 - Ramos-Porto et al. 1996: 219 - Christoffersen 1998: 359 — Barros \& Pimentel 2001: 21 - Guterres et al. 2005: 231, fig. 1 - Coelho et al. 2006: 51 Coelho Filho 2006: 8 - Alves et al. 2008: 49 — Souza et al. 2011: 47 — Almeida et al. 2012: 27 — Soledade \& Almeida 2013: 101 [not Alpheus macrocheles (Hailstone, 1835)].

\section{Diagnosis}

Rostrum without setae, reaching well beyond half length of first segment of antennular peduncle; scaphocerite with lateral margin slightly concave, lateral tooth strong, surpassing distal margin of blade; blade reaching middle of third article of antennular peduncle; distal tooth distinctly exceeding distal 
margin of peduncle. Major cheliped with ischium armed with four spiniform setae; ventromesial margin of merus with five spiniform setae similar in size and shape, spaced almost equidistantly along length of mesial surface of merus; dactylus flattened, laterally twisted, dorsally convex and slightly bulbous distally; plunger developed, with anterior surface distinctly angular. Minor cheliped with ischium armed with four spiniform setae; ventromesial margin of merus with seven spiniform setae similar in size and shape, spaced almost equidistantly along length of mesial surface of merus; dactylus with strong crest on extensor margin. Second pereiopod elongated, slender; ischium slightly longer than merus; carpus with five articles with ratio approximately equal to $4: 2: 1: 1.5: 2$; distolateral margin of uropodal exopod with one mesial tooth and one lateral tooth adjacent to spiniform seta.

\section{Etymology}

The name of this new species is our tribute to the Brazilian carcinologist Dr Marilena Ramos-Porto, retired professor of the Universidade Federal Rural de Pernambuco, Recife. Dr Marilena contributed substantially to the knowledge of the caridean shrimps of the northern and northeastern Brazil.

\section{Material examined}

\section{Holotype}

BRAZIL - ; Pernambuco, off Recife, approximately 20 nautical miles from the coast, REC I, dredge 4; $8^{\circ} 08^{\prime} 51.5^{\prime \prime} \mathrm{S}, 34^{\circ} 34^{\prime} 08.0^{\prime \prime} \mathrm{W} ; 65 \mathrm{~m}$ depth; 7 Feb. 2018; agglomerations of sponges, rhodoliths and calcareous algae; GenBank 16S gene MK918616; MOUFPE 19470.

\section{Paratypes}

BRAZIL - Ceará • 1 đ ; Ceará, seamounts of the North Chain, REVIZEE NE III, stn 75A; $54 \mathrm{~m}$ depth; 7 Apr. 1998; calcareous algae; GenBank 16S gene MK918615; MOUFPE 13703. - Pernambuco •

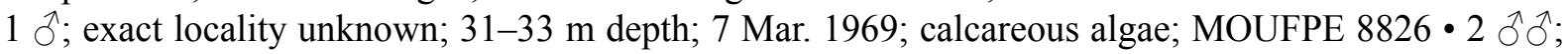
exped. Pesquisador IV, stn 5; $54 \mathrm{~m}$ depth; 12 Apr. 1971; MOUFPE 8856 • 1 क; off Recife, REC I, dredge 6; 809'06.8" S, 34³4'28.4" W; 53 m depth; 7 Feb. 2018; rhodolite crevice; GenBank 16S gene MK918618; CCDB 6120 • 1 q ov; off Recife, REC I, dredge 3; 808'44.2" S, 34³4'23.2" W; 55 m depth; 7 Feb. 2018; rhodolith crevice; GenBank 16S gene MK918617; MZUSP 39146.

\section{Additional material}

BRAZIL - Amapá • 3 ổ; exped. GEOMAR II, stn 116; 81.5 m depth; 13 Sep. 1970; calcareous algae;

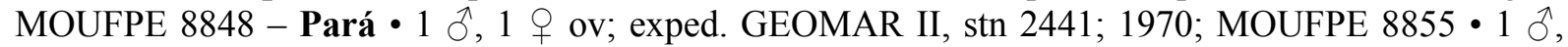
1 ov; exped. GEOMAR II, stn 2528; 60 m depth; 1971; MOUFPE 8836 - Maranhão • 1 \%; Tutóia, RV Almirante Saldanha, stn 1732A; 69 m depth; 30 Oct. 1967; calcareous algae; MOUFPE 8829 • 9 NI; RV Almirante Saldanha, stn 1750; 52 m depth; 6 Nov. 1967; calcareous algae; MOUFPE 8830 - 1 Oे, 1 P; São Luis, RV Almirante Saldanha, stn 1875; 49 m depth; 23 Apr. 1968; calcareous algae; MOUFPE 8831 • 1 NI; Tutóia, RV Almirante Saldanha, stn 1813; 83 m depth; 28 Nov. 1967; calcareous algae; MOUFPE 8837 • 1 क; RV Almirante Saldanha, stn 1751; 44 m depth; 6 Nov. 1967; calcareous algae; MOUFPE 8845 - 1 के; RV Almirante Saldanha, stn 1750; $52 \mathrm{~m}$ depth; 6. Nov. 1967; calcareous algae; MOUFPE 8847 - Ceará • 1 đ̊; REVIZEE NE III, stn 72A; $2^{\circ} 4^{\prime} 48^{\prime \prime} \mathrm{S}, 38^{\circ} 12^{\prime} 0^{\prime \prime}$ W; 8 Jun. 1998; MOUFPE 13647.

\section{Comparative material analyzed}

Alpheus amblyonyx Chace, 1972

FRANCE - Guadeloupe - 1 ; KARUBENTHOS, stn GB20; $16 \mathrm{~m}$ depth; 18 May 2012; MNHNIU-12112 - 1 o ov; KARUBENTHOS, stn GB24; 16 m depth; 18 May 2012; GenBank 16S gene MK714203; MNHN-IU-12026.

MEXICO • 1 NI; Quintana Roo, southeast of Arrecife Chinchorro; 28 Aug. 1990; GenBank 16S gene MK714201; UNAM-CNCR 21271. 
Alpheus macrocheles (Hailstone, 1835)

ANGOLA • 3 우 (2 ov), 1 §̊; Cuanza River; 31 Jan. 1949; RMNH.Crus.D.7821.

CAPE VERDE • 1 q ov, 3 NI; “Tydeman” Cancap-VI, Cape Verde Islands exped., stn 6.109, off Santa Luzia; $16^{\circ} 44^{\prime} \mathrm{N}, 24^{\circ} 46^{\prime} \mathrm{W}$; 55-80 m depth; 16 Jun. 1982; calcareous algae; RMNH.Crus.D.51345 • 1 ○; Tarrafal Bay; 1959; MNHN 3163.

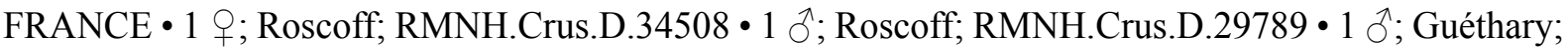
27 Oct. 1947; RMNH.Crus.D.1869.

MOROCCO • 1 q; 3350 $50^{\prime} \mathrm{N}, 07^{\circ} 07^{\prime} \mathrm{W} ; 25$ Jan. 1956; RMNH.Crus.D.34495 • 1 đ’; Témara; 1952; RMNH.Crus.D.34496・ 1 §ో; Témara; 1954; RMNH.Crus.D.34497.

PORTUGAL - Azores • 1 त̂, 1 NI; stn 5.142; 108-118 m depth; 7 Jun. 1981; GenBank 16S gene MK714206; RMNH.Crus.D.51342. - Madeira • 1 đ; Cais de Porto Novo; 18 Aug. 1993; under rocks; RMNH.Crus.D.42706.

SPAIN - Canary Islands • 1 ; ; southeast of Lanzarote, stn 4.070; 41-50 m depth; 20 May 1980; sand and calcareous algae; GenBank 16S gene MK714207; RMNH.Crus.D.51363.

\section{Description}

CARAPACE. Smooth, frontal margin with well-developed sharp rostrum; orbital hoods with well-developed acute teeth originating from anterior margin of orbital hoods (Fig. 1A); rostrum slightly flattened dorsally, distinctly longer than wide, distally tapering and ending in acute point, without setae, reaching well beyond half-length of first article of antennular peduncle (Fig. 1A-B); margin between orbital teeth and rostrum $\mathrm{V}$-shaped with slightly rounded angle (Fig. 1A); orbital process weak. Pterygostomial angle rounded, not anteriorly protruding (Fig. 1B); cardiac notch deep.

HEAD. Eyes with well-developed corneas; ocellar beak projecting, acute, visible in lateral view. Antennular peduncle moderately slender; stylocerite with acute tip reaching distal margin of first article of antennular peduncle; ventromesial carina with very large, triangular tooth bearing small acute point (Fig. 1C); second article of antennular peduncle much longer than visible part of first article, approx. three times longer than wide, twice as long as third article (Fig. 1A-B); lateral flagellum with several groups of aesthetascs extending to article 10. Antenna with basicerite ending in sharp ventrolateral tooth, extending just beyond orbital tooth; carpocerite slightly overreaching scaphocerite and antennular peduncle; scaphocerite with lateral margin slightly concave, ending in strong distolateral tooth distinctly overreaching antennal peduncle and surpassing distal margin of blade (Fig. 1A), latter reaching to middle of third article. Mouthparts typical for Alpheus, as illustrated (Fig. 1D-I). Third maxilliped slender; coxa with lateral plate slightly truncate distally; exopod overreaching antepenultimate article when extended; antepenultimate article somewhat flattened, approximately four times longer than wide, ventral surface sparsely setose; penultimate article about three times longer than wide, slightly broadened distally and densely setose; ultimate article unarmed, distally tapering, with dense transverse rows of long setae (Fig. 1I).

CHELIPEDs. Major cheliped with ischium short, robust, ventromesial surface with four small spiniform setae (Fig. 2F); merus robust, about twice as long as wide, subtriangular in cross-section; ventrolateral margin unarmed; ventromesial margin straight, bearing five small spiniform setae, ending in robust sharp tooth; carpus short, cup-shaped, slightly compressed (Fig. 2F); lateral surface of palm with low crest (inferior crest) starting at approximately 0.6 of palm length, ending in sharp distolateral tooth, latter slightly directed laterally (Fig. 2A); mesial surface convex, smooth, without grooves (Fig. 2B); ventral surface with rounded smooth shoulder slightly projecting into adjacent deep notch, latter extending 


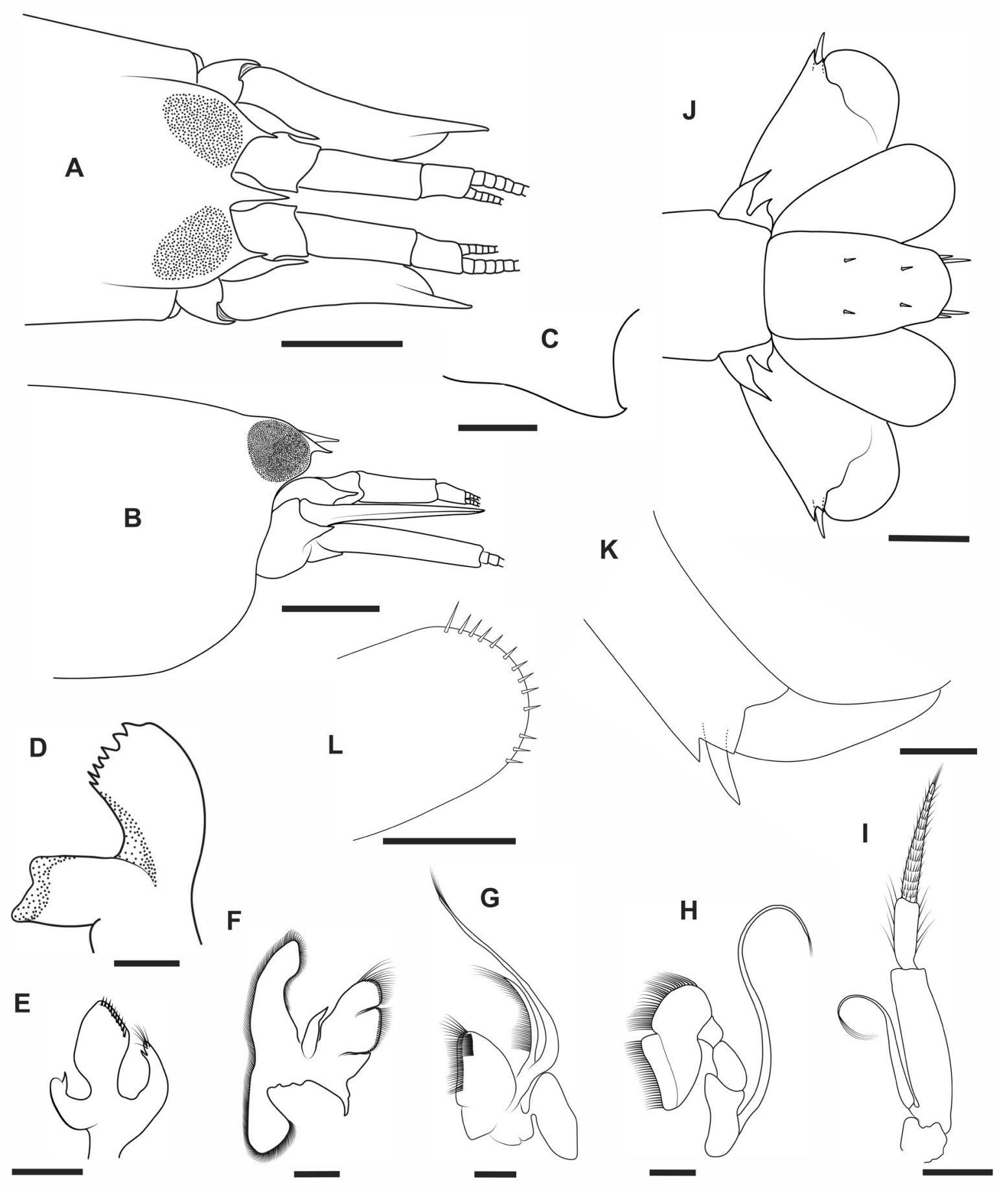

Fig. 1. Alpheus ramosportoae sp. nov. A-D. Holotype, $\widehat{\partial}$, from off Recife, state of Pernambuco, northeastern Brazil (MOUFPE 19470). A. Carapace and cephalic appendages, dorsal view (setae omitted). B. Same, lateral view. C. Tooth on ventromesial carina of antennular peduncle. D. Left mandible, mesial view. E-L. Paratype, ô, from seamounts of the North Chain, Ceará, northeastern Brazil (MOUFPE 13703). E. First maxilla, lateral view. F. Second maxilla, lateral view. G. First maxilliped, lateral view. H. Second maxilliped, lateral view. I. Third maxilliped, lateral view. J. Telson and uropods, dorsal view (setae omitted). K. Uropod, detail of the distolateral angle of the exopod. L. Uropod, detail of the posteerior margin of endopod. Scale bars: A-B, J $=1 \mathrm{~mm} ; \mathrm{C}-\mathrm{I}, \mathrm{K}-\mathrm{L}=0.5 \mathrm{~mm}$. 
transversely to groove on mesial surface (inferior groove); dorsal margin with subcylindrical elevation (plaque crest) ending distally in large adhesive disk; distomesial surface with deep transversally notched crest (superior crest) ending in sharp tooth; distal third of ventral margin with long, robust setae extending to distomesial margin; pollex shorter than dactylus, strongly curved laterally, cutting edge slightly excavate, bearing one small rounded tooth proximally (Fig. 2A); dactylus flattened, laterally twisted, dorsally convex, slightly bulbous distally (Fig. 2A); plunger moderately developed, its proximal margin with sharp angle (Fig. 2E); adhesive disks of dactylus well-developed (Fig. 2A). Minor cheliped not sexually dimorphic; ischium, short, stout, its distomesial margin armed with four spiniform setae; merus broad, subtriangular in cross-section; ventrolateral surface unarmed; ventromesial margin slightly convex, ending in small acute tooth, with seven spiniform setae similar in size and shape, spaced almost equidistantly along entire length of mesial margin; carpus cup-shaped (Fig. 2G); chela strongly compressed; palm with grooves and notches on distal half of lateral surface (Fig. 2C-D); lateral surface with low crest (inferior crest) starting at about middle of palm and ending in acute distolateral tooth (Fig. 2C); mesial surface convex and devoid of depressions or grooves (Fig. 2D); ventral surface smooth, ending in well-defined notch; dorsal margin also smooth, with sub-cylindrical elevation (plaque crest) ending distally in small adhesive disk; distomesial surface with high ridge ending in strong sharp tooth (superior crest); fingers as long as palm (Fig. 2C-D); pollex lightly excavate on cutting edge; dactylus slightly flattened and twisted laterally, with broad crest on extensor margin, bearing small adhesive disk proximally (Fig. 2C-D).

Pereiopods. Second pereiopod elongate, slender; ischium slightly longer than merus; carpus with five subdivisions with ratio approximately equal to $4: 2: 1: 1.5: 2$; chela fingers as long as palm, with small tufts of setae on distal region (Fig. 3A). Third pereiopod with ischium armed with one strong spiniform seta on ventrolateral surface (Fig. 3B); merus five times longer than broad, unarmed distoventrally; carpus slender, about half-length of merus (Fig. 3B); propodus approximately 1.2 times as long as carpus, with about nine robust spiniform setae along ventral margin and one pair of spiniform setae at propodo-dactylar articulation (Fig. 3E); dactylus slightly shorter than half-length of propodus, conical, slightly curved, acute, extensor margin with one subdistal denticle (Fig. 3E, H). Fourth pereiopod similar to third in shape and proportion of articles, slightly less robust (Fig. 3C); ischium armed with one strong spiniform seta on ventrolateral surface (Fig. 3C); propodus with about eight robust spiniform setae along ventral margin and one pair of spiniform setae at propodo-dactylar articulation, extensor margin with one subdistal denticle (Fig. 3F, I). Fifth pereiopod more slender than third and fourth (Fig. 3D); merus slightly longer than carpus; ischium with one spiniform seta; propodus with about eight spiniform setae along ventral margin and nine well-developed rows of setae distolaterally (omitted) (Fig. 3G).

PLEON. Pleonites 1-4 with posteroventral margins broadly rounded, fifth pleonite slightly angular. Telson subrectangular, tapering to posterior margin; proximal margin twice as wide as distal margin; lateral margin slightly convex; dorsal surface with two pairs of spiniform setae, first pair located at telson halflength, second pair at approximately 0.7 of telson length; posterior margin broadly convex, with two pairs of spiniform setae, mesial pair about three times as long as lateral pair (Fig. 1J); anal tubercles well-developed.

Pleopods. With sparse setae on lateral margin of protopod. First pleopod reduced; distal margin of endopod with setae. Second pleopod of male with appendix masculina subequal in length to appendix interna, not reaching distal margin of endopod, with numerous rigid setae distally. Uropod with lateral lobe of protopod ending in strong sharp tooth (Fig. 1J); diaeresis sinuous; distolateral margin of exopod with one mesial tooth and one lateral tooth flanking spiniform seta (Fig. 1K); endopod with row of spiniform setae along distal margin, mesial ones stronger than lateral ones (Fig. 1L). 


\section{Color in life}

Body predominantly reddish; carapace uniformly reddish; pleon reddish with whitish transverse bands and whitish spots on lateral surface; major cheliped palm reddish, with three transverse white patches on both lateral and mesial surfaces, more defined on mesial surface; fingers of both chelae reddish; telson and uropods intensely reddish; protopods of uropods whitish; pereiopods (2-5) pale reddish (Fig. 4AC). This color pattern was homogeneous in all specimens collected.
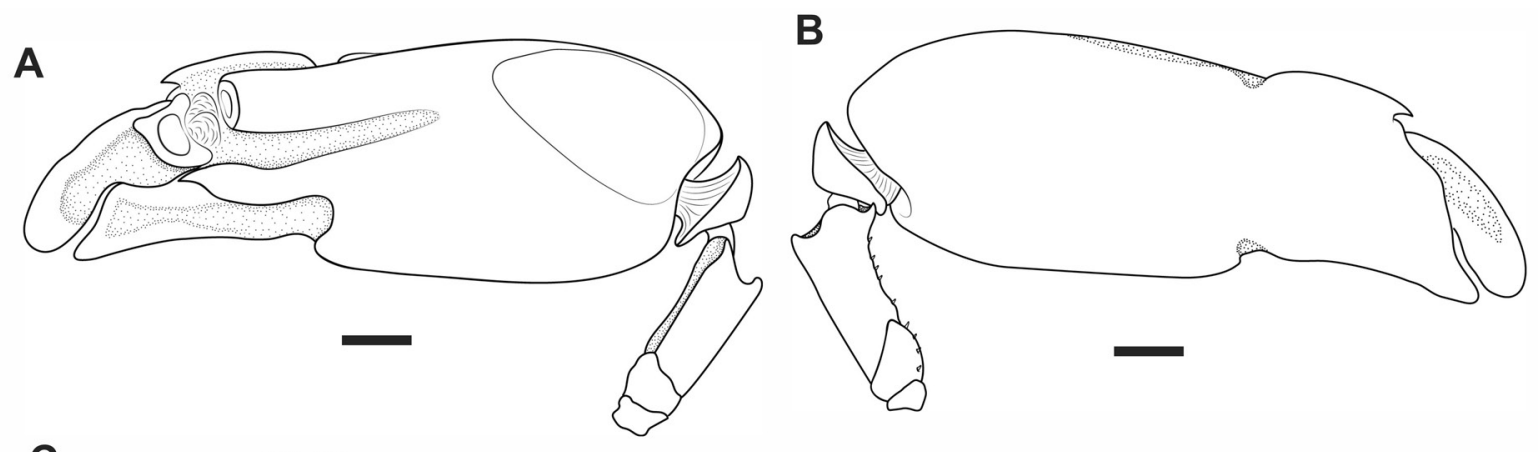

C
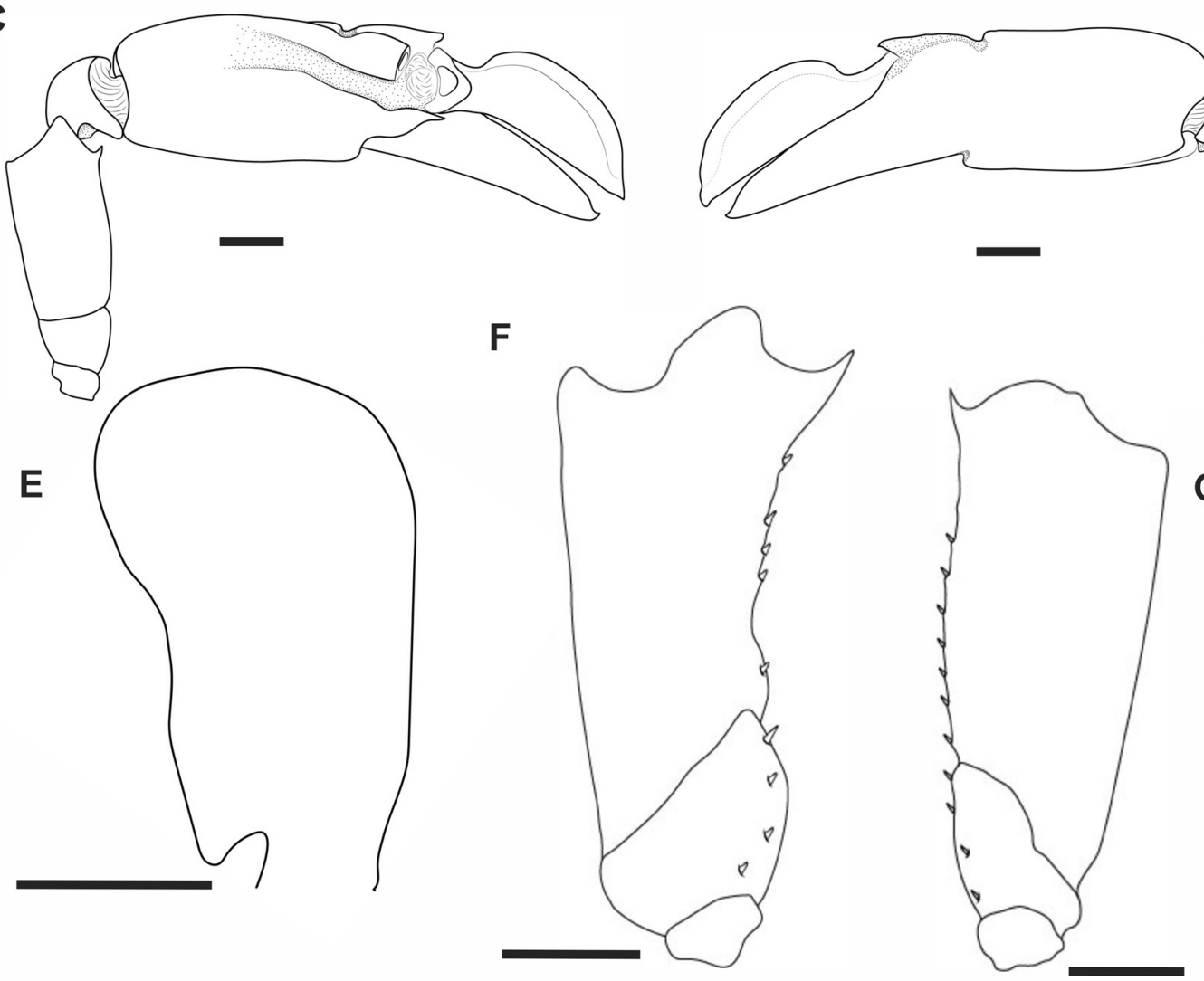

D

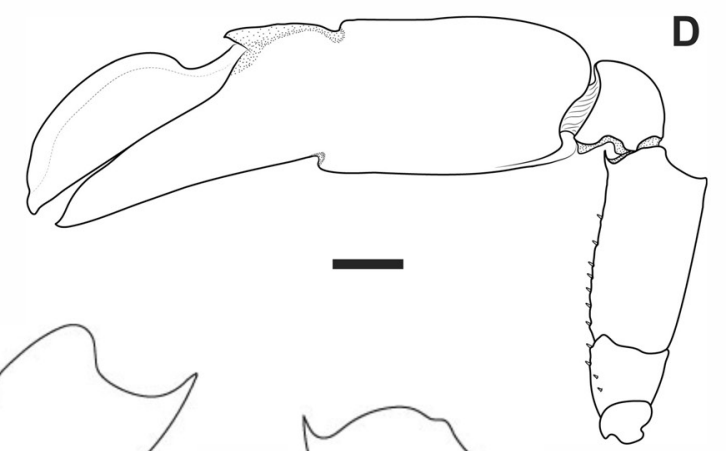

G

Fig. 2. Alpheus ramosportoae sp. nov., paratype, $\hat{\sigma}$, from seamounts of the North Chain, Ceará, northeastern Brazil (MOUFPE 13703). A. Major cheliped, lateral view. B. Same, mesial view. C. Minor cheliped, lateral view. D. Same, mesial view. E. Major chela dactylus, mesial view, detail of plunger. F-G. Detail of spiniform setae on ischium and propodus of major and minor chelae, respectively. Scale bars: $\mathrm{A}-\mathrm{E}=1 \mathrm{~mm} ; \mathrm{F}-\mathrm{G}=0.5 \mathrm{~mm}$. 


\section{Habitat}

On sand mixed with calcareous algae, rhodoliths and sponges (Fig. 4D-F), at depths ranging from 33 to $90 \mathrm{~m}$ (Ramos-Porto 1979, as A. macrocheles; present study).

\section{Distribution}

Brazil: Amapá, Pará, Maranhão, Ceará and Pernambuco (Ramos-Porto 1979, as A. macrocheles; present study).

\section{Molecular analysis}

The best-fit substitution model selected with a corrected Bayesian information criterion was TPM3uf $+\mathrm{I}$, assuming the nucleotide frequencies $\mathrm{A}=0.2847, \mathrm{C}=0.1194, \mathrm{G}=0.2561, \mathrm{~T}=0.3398$, replacement rates $\mathrm{AC}=0.0010, \mathrm{AG}=4.5910, \mathrm{AT}=1, \mathrm{CG}=0.0010, \mathrm{CT}=4.5910, \mathrm{GT}=1$, proportion of invariable sites $=0.5410$. The Bayesian Inference analysis (Fig. 5) retrieved two clades, one being formed by

\section{A}
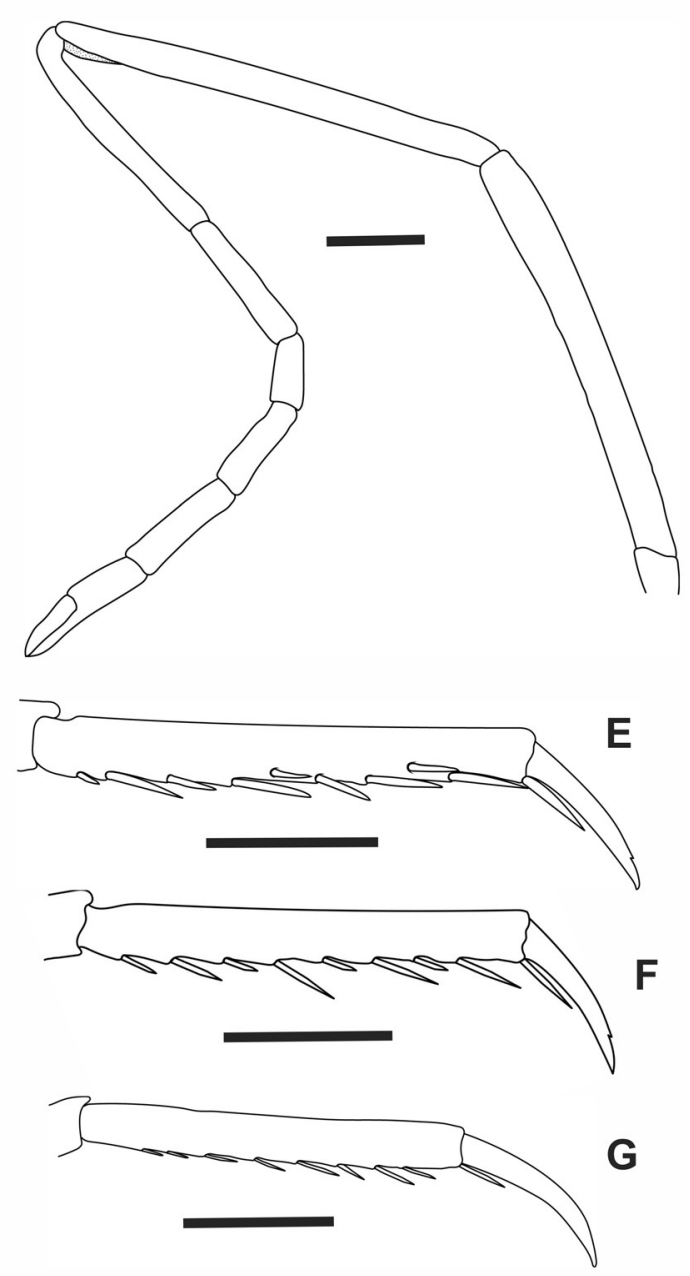
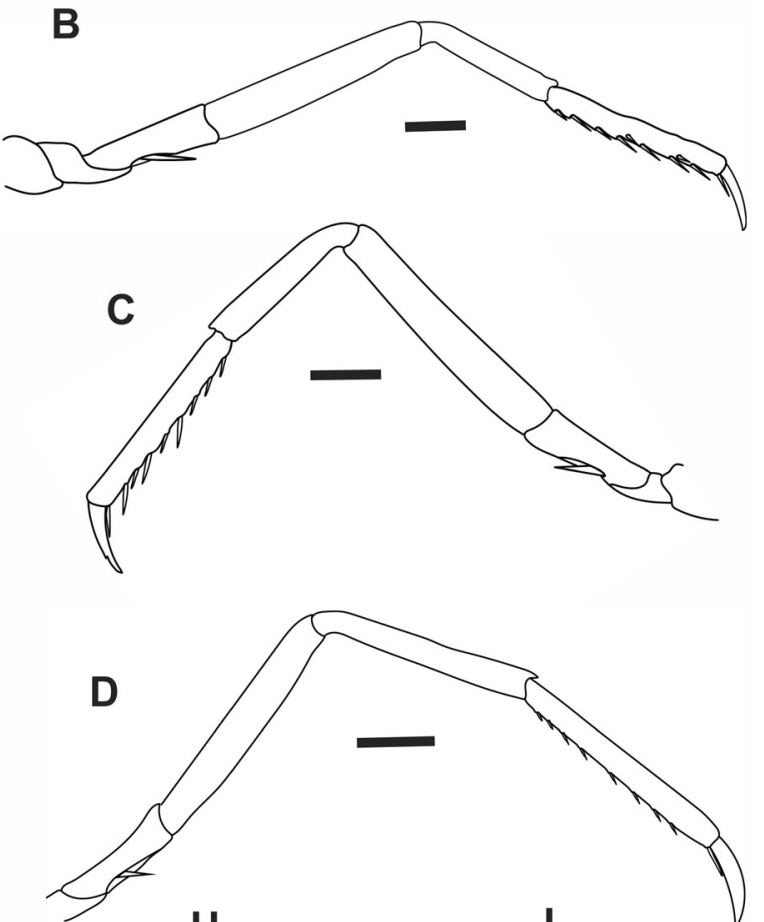

H
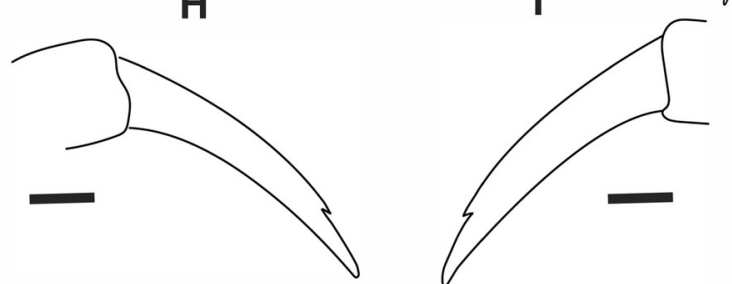

Fig. 3. Alpheus ramosportoae sp. nov., paratype, $\hat{\sigma}$, from seamounts of the North Chain, Ceará, northeastern Brazil (MOUFPE 13703). A. Second pereiopod, lateral view. B. Third pereiopod, lateral view. C. Fourth pereiopod, lateral view. D. Fifth pereiopod, lateral view. E-G. Third to fifth pereiopods, detail of propodus, lateral view. $\mathbf{H}-\mathbf{I}$. Third and fourth pereiopods, detail of dactylus. Scale bars: $\mathrm{A}-\mathrm{G}=$ $0.5 \mathrm{~mm} ; \mathrm{H}-\mathrm{I}=0.25 \mathrm{~mm}$. 
A. amblyonyx and another including $A$. ramosportoae sp. nov. as sister to a clade formed by $A$. crockeri (Armstrong, 1941), A. puapeba and A. macrocheles. Genetic distance estimates (Table 2) support these results. The range of the genetic distance values between $A$. ramosportoae sp. nov. and other species was 15.9-22.9\% according to the TPM3 model. Alpheus ramosportoae sp. nov., as well as A. amblyonyx and A. macrocheles, show no significant intraspecific divergence in $16 \mathrm{~S}$ sequences.

\section{Discussion}

Alpheus ramosportoae sp. nov. can be separated from other Atlantic representatives of the A. macrocheles complex (sensu Anker \& De Grave 2012, see above) by morphology, DNA and coloration. Alpheus ramosportoae sp. nov. may be distinguished from most of them by the presence of a small subdistal
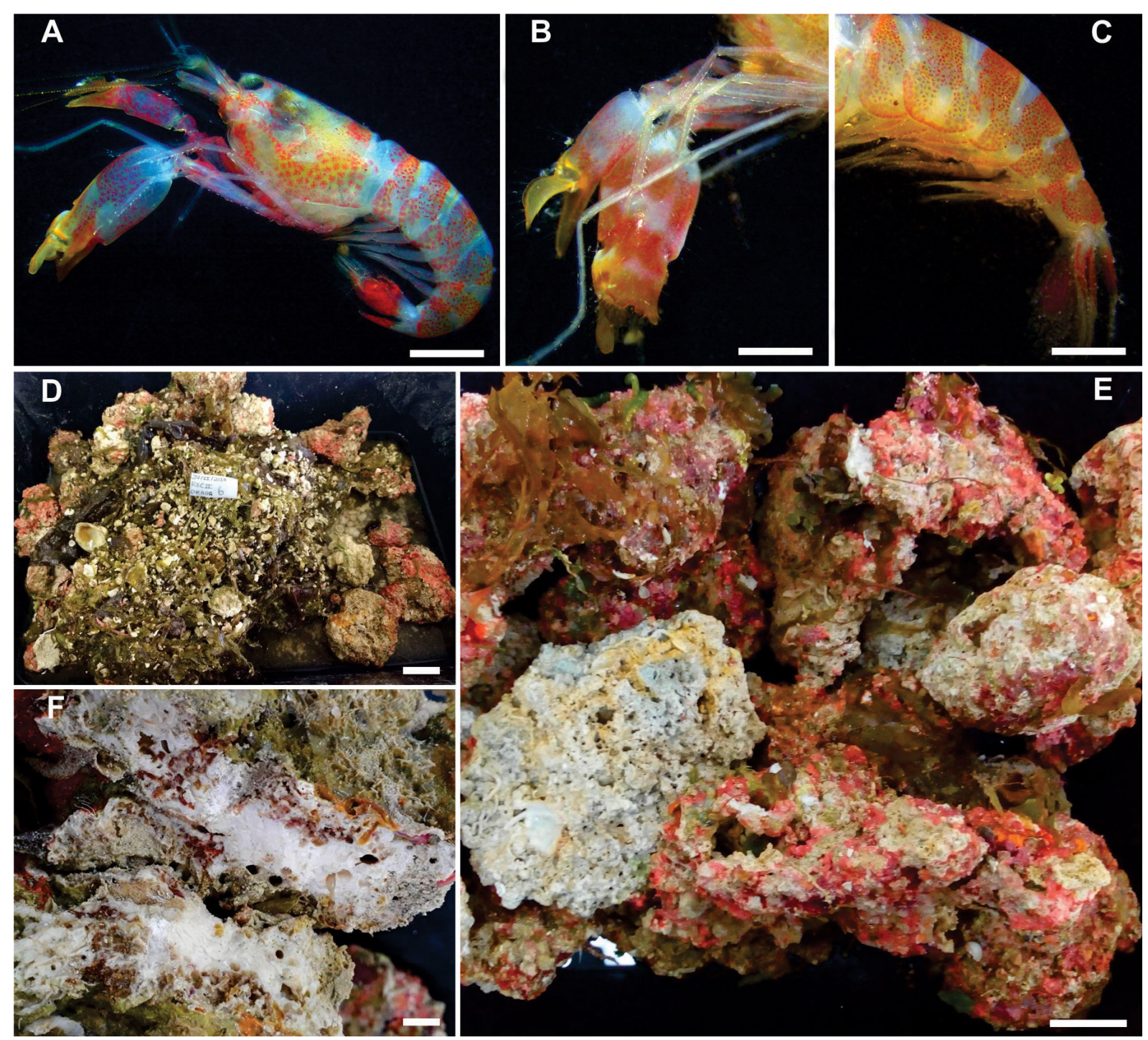

Fig. 4. Alpheus ramosportoae sp. nov. from off Recife, state of Pernambuco, northeastern Brazil. A-C. Color pattern in life of the species. A. Body color pattern, lateral view. B. Coloration of major (mesial view) and minor (lateral view) chelipeds. C. Coloration of pleon, lateral view. D-F. Substrates where the specimens were obtained. D. Calcareous algae, sponges and sandy sediment clusters. E. External appearance of rhodolith fragments. F. Detail of a fragment of rhodolith broken in half, showing crevices from which specimens were retrieved. Scale bars: A-C $=1 \mathrm{~mm} ; \mathrm{D}-\mathrm{F}=2 \mathrm{~cm}$. 
denticle on the extensor margin of the dactylus of pereiopods 3-4, a character shared only with A. macrocheles and A. amblyonyx (Fig. 3H-I). Furthermore, A. ramosportoae sp. nov. can be separated from $A$. cedrici and A. puapeba by the presence of a strong crest on the extensor surface of the minor cheliped dactylus (absent in A. cedrici and A. puapeba) and two teeth on the distolateral margin of the uropodal exopod (vs only one tooth in A. cedrici and A. puapeba) (cf. Fig. 2C-D and Christoffersen 1979: fig. 16F-H; Anker \& De Grave 2012: fig. 2A-C). The new species can be distinguished from A. platydactylus by the presence of a well-developed plunger on the major cheliped dactylus (absent in A. platydactylus) (cf. Fig. 2E and Crosnier \& Forest 1966: fig. 2F) and by the absence of tubercles on the ventral surface of the major chela palm (present in A. platydactylus). Alpheus ramosportoae sp. nov. differs from $A$. pouang by the presence of a well-defined ventral notch on the major cheliped palm (obsolete in A. pouang) (cf. Fig. 2A-B and Christoffersen 1979: fig. 15J). Finally, the new species can be distinguished from A. lentiginosus by the presence of a well-defined plunger on the major cheliped dactylus (rudimentary in A. lentiginosus) (cf. Fig. 2E and Anker \& Nizinski 2011: fig. 1G) and the absence of a minute subdistal denticle on the flexor surface of the pereiopods 3-5 dactyli (present in A. lentiginosus) (cf. Fig. 3H-I and Anker \& Nizinski 2011: fig. 2C, E).

Alpheus ramosportoae sp. nov. differs from A. amblyonyx and A. macrocheles by several morphological characters listed in Table 3. The most conspicuous difference between the new species and A. amblyonyx is the presence of a strong crest on the extensor surface of the minor cheliped dactylus in the former vs its absence in the latter (cf. Fig. 2C-D and Chace 1972: fig. 16L-M, Y, V and Soledade et al. 2019: fig. 5C-D). Other differences between A. ramosportoae sp. nov. and A. amblyonyx include the second article of the antennular peduncle twice as long as the third (vs second article less than 1.5 times the length of the third in A. amblyonyx) and the distolateral tooth of the scaphocerite overreaching the

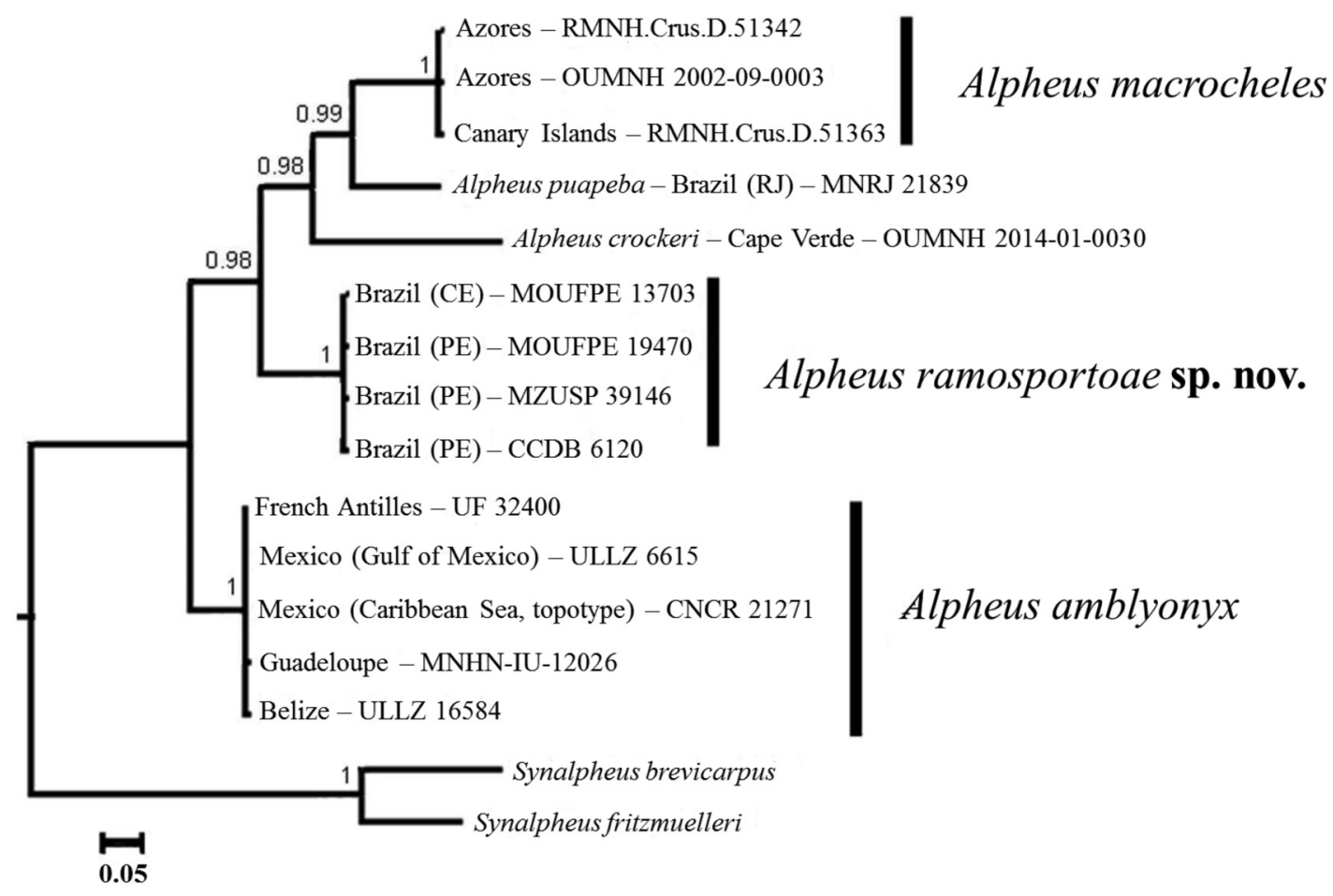

Fig. 5. Bayesian Inference Tree of the $16 \mathrm{~S}$ gene including specimens of Alpheus ramosportoae sp. nov., selected species of the A. macrocheles complex, and Synalpheus C.S. Bate, 1888. Numbers close to nodes represent posterior probabilities. Abbreviations: $\mathrm{CE}=$ state of Ceará; $\mathrm{PE}=$ state of Pernambuco. 
Table 2. Genetic distance matrix of the $16 \mathrm{~S}$ gene between Alpheus ramosportoae sp. nov. and some selected species assigned to the $A$. macrocheles species complex, as well as Synalpheus C.S. Bate, 1888, built with the TPM3 model. The number of specimens used in the analysis for each taxon is presented along with the collection localities.

\begin{tabular}{|c|c|c|c|c|c|c|}
\hline & 1 & 2 & 3 & 4 & 5 & 6 \\
\hline $\begin{array}{l}\text { 1. Alpheus amblyonyx Chace, } 1972 \\
\text { (5 specs, Belize, French Antilles, } \\
\text { Guadeloupe and Mexico) }\end{array}$ & 0 & & & & & \\
\hline $\begin{array}{l}\text { 2. Alpheus crockeri (Armstrong, 1941) } \\
\text { (1 spec., Cape Verde) }\end{array}$ & 25.1 & - & & & & \\
\hline $\begin{array}{l}\text { 3. Alpheus macrocheles (Hailstone, 1835) } \\
\text { (3 specs, Azores, Canary Islands) }\end{array}$ & 21.0 & 21.9 & 0 & & & \\
\hline $\begin{array}{l}\text { 4. Alpheus puapeba Christoffersen, } 1979 \\
\text { (1 spec., Rio de Janeiro - Brazil) }\end{array}$ & 19.3 & 21.9 & 14.5 & 0 & & \\
\hline $\begin{array}{l}\text { 5. Alpheus ramosportoae sp. nov. } \\
\text { (4 specs, Recife - Brazil) }\end{array}$ & 15.9 & 22.9 & 18.3 & 22.2 & 0 & \\
\hline $\begin{array}{l}\text { 6. Synalpheus spp. } \\
\text { (2 specs, Gulf of Mexico and Brazil) }\end{array}$ & $33.3-34.7$ & $38.4-40.4$ & $39.4-41.9$ & $34.9-38.2$ & $39.9-41.2$ & 15.4 \\
\hline
\end{tabular}

distal margin of the antennular peduncle (vs reaching to the distal margin of the antennular peduncle in A. amblyonyx) (see Table 3).

The presence of a strong crest on the extensor surface of the minor cheliped dactylus is a feature shared by A. ramosportoae sp. nov. and A. macrocheles (cf. Crosnier \& Forest 1966: fig. 2C). However, A. ramosportoae sp. nov. differs from $A$. macrocheles by the longer rostrum, reaching well beyond midlength of the first article of the antennular peduncle (vs only reaching it in A. macrocheles; cf. Soledade et al. 2019: fig. 1A-B); a well-developed plunger on the major cheliped dactylus (vs rudimentary and flat, with a small tooth on the proximal surface, in A. macrocheles; cf. Soledade et al. 2019: fig. 2I-J); and the presence of two well-defined teeth on the distolateral margin of the uropodal exopod (vs one acute lateral tooth and one blunt mesial lobe in A. macrocheles; cf. Soledade et al. 2019: fig. 1J) (Table 3).

The genetic analysis corroborated the separation of $A$. ramosportoae sp. nov. from both A. amblyonyx and $A$. macrocheles. The four specimens of $A$. ramosportoae sp. nov. included in the Bayesian analysis formed a single clade, very distinct from all the other species included. Pairwise genetic distances obtained in this analysis (15.9\% between $A$. ramosportoae sp. nov. and A. amblyonyx; $18.3 \%$ between A. ramosportoae sp. nov. and $A$. macrocheles) are consistent with the values used for the separation of cryptic and pseudocryptic lineages within Alpheus (Mathews et al. 2002; Mathews 2006; Almeida et al. 2013, 2014).

The new species also shows marked differences in the color pattern, e.g., compared to specimens of A. amblyonyx from Guadeloupe and Panama, as well as specimens of $A$. macrocheles from the Mediterranean coast of Spain and Madeira (cf. Anker \& De Grave 2012: fig. 4), especially in the 


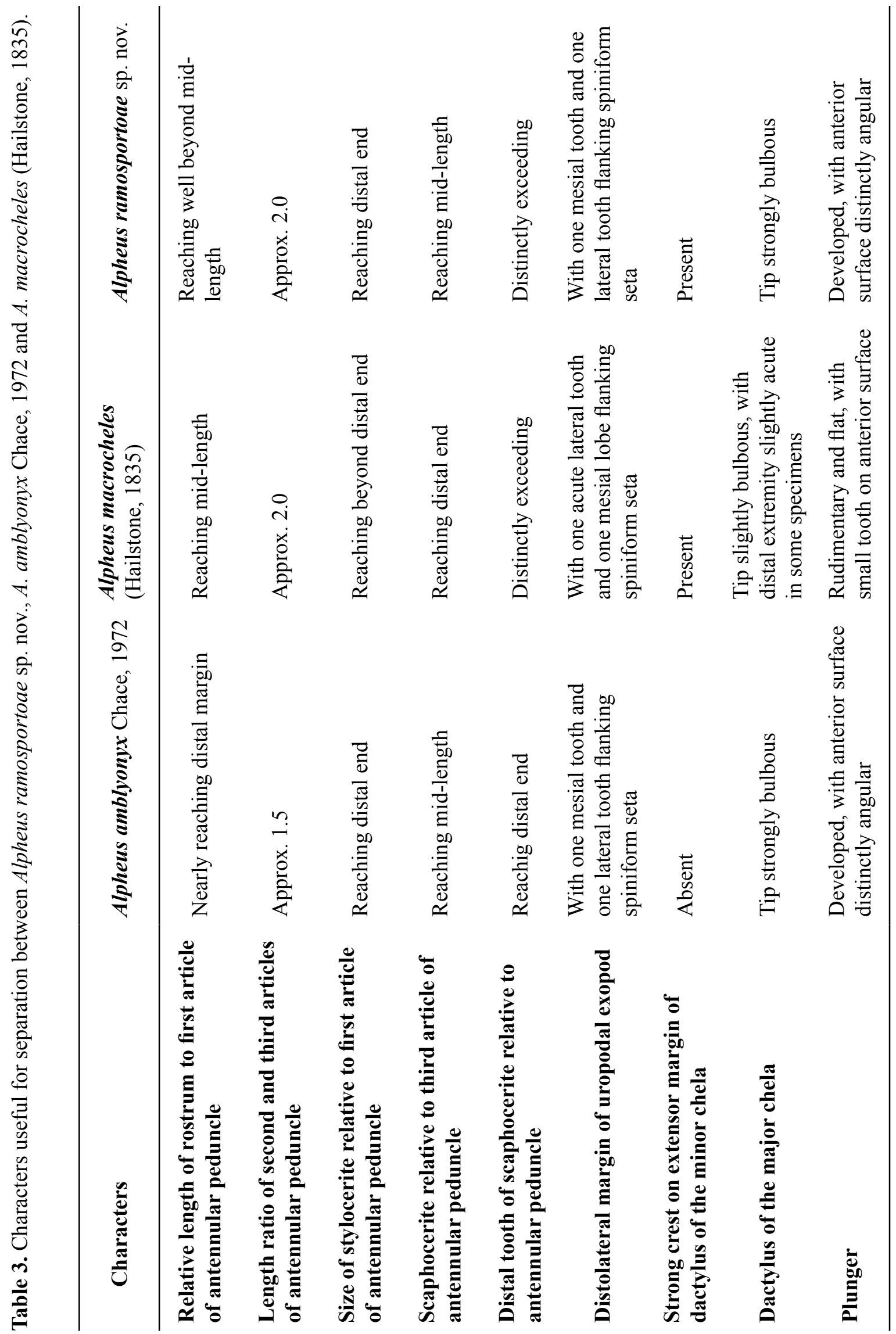


banding pattern of the pleon. In A. amblyonyx and A. macrocheles, the pleon is uniformly reddish, not banded (cf. Anker \& De Grave 2012: fig. 4A-D). In contrast, in A. ramosportoae sp. nov., the pleon is conspicuously banded and also has whitish blotches laterally (Fig. 4A), almost as in A. cedrici (cf. Anker \& De Grave 2012: fig. 3). The color pattern of the major and minor chelae of A. ramosportoae sp. nov. somewhat resembles that of a specimen of $A$. amblyonyx from Guadeloupe in Anker \& De Grave (2012). Both have conspicuous white patches and spots on the mesial surface of the palm; however, in A. amblyonyx, the patches / spots are sharper (better defined) and thus more conspicuous.

Most of the material previously reported as A. macrocheles from Brazil (e.g., Coelho \& Ramos 1972; Ramos-Porto 1979; Fausto Filho 1980; Coelho et al. 1986; Ramos-Porto et al. 1996; Guterres et al. 2005) was not deposited in reference collections and could not be located. As mentioned above, these records lack detailed morphological accounts with illustrations and thus cannot be verified. A large part of Ramos-Porto's material (e.g., material from the Expeditions GEOMAR II-III and NORTE\ NORDESTE I-II) was located in the Museu de Oceanografia Professor Petrônio Alves Coelho and most of this material corresponds to A. ramosportoae sp. nov. From a total of 15 lots analyzed by Ramos-Porto (1979), only one female from Amapá (GEOMAR II 114, 12.IX.1970) was not located. The specimens of the other lots, with a few exceptions, are in good condition for analysis, including the three specimens illustrated by Ramos-Porto (1979), and matched the characteristics of the new species. Based on the absence of $A$. macrocheles in the MOUFPE collection and in other large national collections visited (MNRJ and MZUSP) and the results of our previous contribution (Soledade et al. 2019), it appears that A. macrocheles is restricted to the eastern Atlantic, including Mediterranean Sea.

\section{Acknowledgements}

The authors thank Jesser Fidelis de Souza Filho (MOUFPE), Marcos Tavares (MZUSP), Irene Cardoso (MNRJ), Fernando Álvarez and José Luis Villalobos (UNAM), Charles Fransen and Karen van Dorp $(\mathrm{RMNH})$, Danielle Guinot and Laure Corbari (MNHN), for donations and loans of specimens and support during visits to the collections under their care. JAS thanks Dr Sammy de Grave for his support and kindness during his museum visit.

\section{Funding}

This project was mainly supported by Conselho Nacional de Desenvolvimento Científico e Tecnológico - CNPq (Universal 444459/2014-6, 421193/2018-2 to MT and 421963/2016-6 to AOA), and Fundação de Amparo à Ciência e Tecnologia do Estado de Pernambuco - FACEPE (APQ-0572-2.04/15). Additional support for this project was provided by research grants from Fundação de Amparo à Ciência e Tecnologia do Estado de São Paulo - FAPESP (Temático Biota 2010/50188-8 and 2018/13685-5; PROTAX 2016/50376-5) and Coordenação de Aperfeiçoamento de Pessoal de Nível Superior - CAPES - Código de Financiamento 001 (Ciências do Mar II Proc. 2005/2014-23038.004308/2014-14) to FLM. Some collections and analyses were conducted under support of U.S. National Science Foundation grants NSF/BS\&I DEB-0315995 and NSF/AToL EF-0531603 to Darryl L. Felder at the University of Louisiana at Lafayette. AOA and FLM thank CNPq for ongoing research scholarships (PQ 305939/20157 and 304968/2014-5, respectively). GOS thanks CAPES (Finance Code 001) for support in the form of a $\mathrm{PhD}$ scholarship.

\section{References}

Almeida A.O., Boehs G., Araújo-Silva C.L. \& Bezerra L.E.A. 2012. Shallow-water caridean shrimps from southern Bahia, Brazil, including the first record of Synalpheus ul (Ríos \& Duffy, 2007) (Alpheidae) in the southwestern Atlantic Ocean. Zootaxa 3347: 1-35. https://doi.org/10.11646/zootaxa.3347.1.1 
Almeida A.O., Terossi M., Araújo-Silva C.L. \& Mantelatto F.L. 2013. Description of Alpheus buckupi spec. nov., a new amphi-Atlantic snapping shrimp (Caridea: Alpheidae), based on morphological and molecular data. Zootaxa 3652: 437-452. https://doi.org/10.11646/zootaxa.3652.4.3

Almeida A.O., Terossi M. \& Mantelatto F.L. 2014. Morphology and DNA analyses reveal a new cryptic snapping shrimp of the Alpheus heterochaelis Say, 1818 (Decapoda: Alpheidae) species complex from the western Atlantic. Zoosystema 36: 53-71. https://doi.org/10.5252/z2014n1a4

Alves M.L., Ramos-Porto M. \& Viana G.F.S. 2008. Checklist of the decapods (Crustacea) from the Fernando de Noronha Archipelago, Brazil. Zootaxa 1881: 43-68.

https://doi.org/10.11646/zootaxa.1881.1.2

Anker A. 2012. Revision of the western Atlantic members of the Alpheus armillatus H. Milne Edwards, 1837 species complex (Decapoda, Alpheidae), with description of seven new species. Zootaxa 3386: 1-109. https://doi.org/10.11646/zootaxa.3386.1.1

Anker A. \& De Grave S. 2012. Description of Alpheus cedrici sp. n., a strikingly coloured snapping shrimp (Crustacea, Decapoda, Alpheidae) from Ascension Island, central Atlantic Ocean. ZooKeys 183: 1-15. https://doi.org/10.3897/zookeys.183.3073

Anker A. \& Nizinski M. 2011. Description of the new deep-water species of Alpheus Fabricius, 1798 from the Gulf of Mexico (Crustacea, Decapoda, Alpheidae). Zootaxa 2925: 49-56.

https://doi.org/10.11646/zootaxa.2925.1.5

Anker A., Ahyong S.T., Noël P.Y. \& Palmer A.R. 2006. Morphological phylogeny of alpheid shrimps: parallel preadaptation and the origin of a key morphological innovation, the snapping claw. Evolution 60: 2507-2528. https://doi.org/10.1111/j.0014-3820.2006.tb01886.x

Anker A., Hurt C. \& Knowlton N. 2009. Description of cryptic taxa within the Alpheus bouvieri A. Milne-Edwards, 1878 and $A$. hebes Kim \& Abele, 1988 species complexes (Crustacea: Decapoda: Alpheidae). Zootaxa 2153: 1-23. https://doi.org/10.11646/zootaxa.2153.1.1

Banner A.H. 1953. The Crangonidae, or snapping shrimp, of Hawaii. Pacific Science 7: 3-147.

Barros M.P. \& Pimentel F.R. 2001. A fauna de Decapoda (Crustacea) do Estado do Pará, Brasil: Lista preliminar das espécies. Boletim do Museu Paraense Emilio Goeldi, série Zoologia 17: 15-41.

Bracken H.D., De Grave S. \& Felder D.L. 2009. Phylogeny of the Infraorder Caridea based on mitochondrial and nuclear genes (Crustacea: Decapoda). In: Martin J.W., Crandall K.A. \& Felder D.L. (eds) Decapod Crustacean Phylogenetics: 281-305. Crustacean Issues 18. CRC Press, Boca Raton, London, New York.

Bracken-Grissom H.D., Robles R. \& Felder D.L. 2014. Molecular phylogenetics of American snapping shrimps allied to Alpheus floridanus Kingsley, 1878 (Crustacea: Decapoda: Alpheidae). Zootaxa 3895: 492-502. https://doi.org/10.11646/zootaxa.3895.4.2

Chace Jr. F.A. 1972. The shrimps of the Smithsonian-Bredin Caribbean Expeditions with a summary of the West Indian shallow-water species (Crustacea: Decapoda: Natantia). Smithsonian Contributions to Zoology 98: 1-179. https://doi.org/10.5479/si.00810282.98

Christoffersen M.L. 1979. Decapod Crustacea: Alpheoida. Campagne de la Calypso au large des côtes atlantiques de l'Amérique du Sud (1961-1962). I. 36. Annales de l'Institute Océanographique, Monaco Suppl. 55: 297-377.

Christoffersen M.L. 1998. Malacostraca. Eucarida. Caridea. Crangonoidea and Alpheoidea (Except Glyphocrangonidae and Crangonidae). In: Young P.S. (ed) Catalogue of Crustacea of Brazil, Série livros n. 6: 351-372. Museu Nacional, Rio de Janeiro. 
Coelho P.A. \& Ramos M.A. 1972. A constituição e a distribuição da fauna de decápodos do litoral leste da América do Sul entre as latitudes de $5^{\circ} \mathrm{N}$ e $39^{\circ} \mathrm{S}$. Trabalhos Oceanográficos da Universidade Federal de Pernambuco 13: 133-236. https://doi.org/10.5914/tropocean.v13i1.2555

Coelho P.A. \& Ramos-Porto M.A. 1980. Crustáceos decápodos da costa do Maranhão, Brasil. Boletim do Instituto Oceanográfico 29: 135-138. https://doi.org/10.1590/S0373-55241980000200028

Coelho P.A. \& Ramos-Porto M.A. 1995. Distribuição ecológica dos crustáceos decápodos marinhos do Nordeste do Brasil. Trabalhos Oceanográficos da Universidade Federal de Pernambuco 23: 113-127. https://doi.org/10.5914/tropocean.v23i1.2682

Coelho P.A., Ramos-Porto M. \& Koening M.L. 1980. Biogeografia e bionomia dos crustáceos do litoral equatorial brasileiro. Trabalhos Oceanográficos da Universidade Federal de Pernambuco 15: 7-138. https://doi.org/10.5914/tropocean.v15i1.2573

Coelho P.A., Ramos-Porto M. \& Calado T.C.S. 1986. Litoral do Rio Grande do Norte: Decapoda. Caderno Ômega da Universidade Federal Rural de Pernambuco, Série Ciências Aquáticas, Recife 2: 79-105.

Coelho P.A., Almeida A.O., Souza-Filho J.F., Bezerra L.E.A. \& Giraldes B.W. 2006. Diversity and distribution of the marine and estuarine shrimps (Dendrobranchiata, Stenopodidea and Caridea) from North and Northeast Brazil. Zootaxa 1221: 41-62. https://doi.org/10.11646/zootaxa.1221.1.5

Coelho Filho P.A. 2006. Checklist of the Decapods (Crustacea) from the outer continental shelf and seamounts from Northeast of Brazil - REVIZEE Program (NE III). Zootaxa 1184: 1-27.

https://doi.org/10.11646/zootaxa.1184.1.1

Coleman C.O. 2003 "Digital inking": How to make perfect line drawings on computers. Organisms, Diversity and Evolution 3 (4): 303-304. https://doi.org/10.1078/1439-6092-00081

Coleman C.O. 2009. Drawing setae the digital way. Zoosystematics and Evolution 85: 305-310. https://doi.org/10.1002/zoos.200900008

Coutière H. 1897. Note sur quelques genres nouveaux ou peu connus d'Alphéidés, formant la sousfamille des Alphéopsidés. Bulletin du Muséum d'histoire naturelle 2: 380-386.

Coutière H. 1905. Les Alpheidae. In: Gardiner J.S. (ed.) The Fauna and Geography of the Maldive and Laccadive Archipelagoes. Being the account of the work carried on and of the Collections made by an Expedition during the years 1899 and 1900: 852-921. University Press, Cambridge.

https://doi.org/10.5962/bhl.title.10215

Crandall K.A. \& Fitzpatrick Jr. J.F. 1996 Crayfish molecular systematics: using a combination of procedures to estimate phylogeny. Systematic Biology 45: 1-26. https://doi.org/10.1093/sysbio/45.1.1

Crosnier A. \& Forest J. 1966. Crustacés Décapodes: Alpheidae. In: Campagnes de la Calypso dans le Golfe de Guinée et aux Îles Principe, São Tomé et Annobon (1956), et Campagne aux Îles du Cap Vert (1959). Part 19: Résultats Scientifiques des Campagnes de la Calypso 7(27). Annales de l'Institut Océanographique de Monaco 44: 199-314.

Darriba D., Taboada G.L., Doallo R. \& Posada D. 2012. jModelTest 2: more models, new heuristics and parallel computing. Nature Methods 9: 772. https://doi.org/10.1038/nmeth.2109

De Grave S. \& Fransen C.H.J.M. 2011. Carideorum catalogus: the recent species of the dendrobranchiate, stenopodidean, procarididean and caridean shrimps (Crustacea: Decapoda). Zoologische Mededelingen 89: $195-589$. 
De Grave S., Anker A., Dworschak P.C., Clark P.F. \& Wirtz P. 2017. An updated checklist of the marine Decapoda of Asension Island, central Atlantic Ocean. Journal of the Marine Biological Association of the United Kingdom 97: 759-770. https://doi.org/10.1017/S0025315414001295

Dehghani A., Sari A. \& Naderloo R. 2019. Three new species of narrowly endemic snapping shrimp, genus Alpheus (Decapoda: Caridea: Alpheidae) from the Persian Gulf. Journal of the Marine Biological Association of the United Kingdom 99: 911-920. https://doi.org/10.1017/S0025315418000693

Drummond A.J., Suchard M.A., Xie D. \& Rambaut A. 2012. Bayesian phylogenetics with BEAUti and the BEAST 1.7. Molecular Biology and Evolution 29: 1969-1973.

https://oi.org/10.1093/molbev/mss075

Edgar R.C. 2004. MUSCLE: multiple sequence alignment with high accuracy and high throughput. Nucleic Acids Research 32: 1792-1797. https://doi.org/10.1093/nar/gkh340

Fausto Filho J. 1980. Crustáceos estomatópodos e decápodos dos substratos de cascalho do nordeste brasileiro. Ciências Agronômicas 10: 109-124.

Guterres L.F.R., Melo G.A.S. \& Guterres P.M.C. 2005. Novos registros da ocorrência de Alpheus macrocheles (Crustacea, Caridea, Alpheidae) na costa do Brasil. Biociências 13: 231-233.

Hailstone S. 1835. The species of crustaceous animals discovered and described by Mr. Hailstone, and illustrated and annotated upon by Mr. Westwood. The Magazine of Natural History and Journal of Zoology, Botany, Mineralogy, Geology and Meteorology 8: 394-395.

Hall T. 2005. BioEdit 7.0.5. North Carolina State University, Department of Microbiology. Available from http://www.mbio.ncsu.edu/BioEdit/bioedit.html [accessed 30 Oct. 2019].

Holthuis L.B. 1951. The caridean Crustacea of tropical West Africa. Atlantide Report 2: 1-187.

Kim W. \& Abele L.G. 1988. The snapping shrimp genus Alpheus from the eastern Pacific (Decapoda, Caridea, Alpheidae). Smithsonian Contributions to Zoology 454: 1-119.

https://doi.org/10.5479/si.00810282.454

Komai T. \& Ohtomi J. 2018. A new deep-sea species of the snapping shrimp genus Alpheus Fabricius, 1798 (Decapoda: Caridea: Alpheidae) from Kagoshima Bay, Japan. Zootaxa 4434: 99-110.

https://doi.org/10.11646/zootaxa.4434.1.6

Mantelatto F.L., Robles R., Schubart C.D. \& Felder D.L. 2009. Molecular phylogeny of the genus Cronius Stimpson, 1860, with reassignment of C. tumidulus and several American species of Portunus to the genus Achelous De Haan, 1833 (Brachyura: Portunidae). In: Martin J.L., Crandall K.A. \& Felder D.L. (eds) Decapod Crustacean Phylogenetics: 567-579. CRC Press, Boca Raton, Florida, USA.

Mantelatto F.L., Terossi M., Negri M., Buranelli R.C., Robles R., Magalhães T., Tamburus A.F., Rossi N. \& Miyazaki M.J. 2018. DNA sequence database as a tool to identify decapod crustaceans on the São Paulo coastline. Mitochondrial DNA Part A 29: 805-815. https://doi.org/10.1080/24701394.2017.1365848

Mathews L.M. 2006. Cryptic biodiversity and phylogeographic patterns in a snapping shrimp species complex. Molecular Ecology 15: 4049-4063. https://doi.org/10.1111/j.1365-294X.2006.03077.x

Mathews L.M. \& Anker A. 2009. Molecular phylogeny reveals extensive ancient and ongoing radiations in a snapping shrimp species complex (Crustacea, Alpheidae, Alpheus armillatus). Molecular Phylogenetics and Evolution 50: 268-281. https://doi.org/10.1016/j.ympev.2008.10.026

Mathews L.M., Schubart C.D., Neigel J.E. \& Felder D.L. 2002. Genetic, ecological, and behavioural divergence between two sibling snapping shrimp species (Crustacea: Decapoda: Alpheus). Molecular Ecology 11: 1427-1437. https://doi.org/10.1046/j.1365-294X.2002.01539.x 
Miller M.A., Pfeiffer W. \& Schwartz T. 2010. Creating the CIPRES Science Gateway for inference of large phylogenetic trees. Proceedings of the Gateway Computing Environments Workshop (GCE): 1-8. https://doi.org/10.1109/GCE.2010.5676129

Rambaut A., Suchard M.A., Xie D. \& Drummond A.J. 2014. Tracer v1.6. Available from http://beast.bio.ed.ac.uk/Tracer

Ramos-Porto M. 1979. Ocorrência de Alpheus macrocheles (Hailstone) (Crustacea: Decapoda: Alpheidae) no norte e nordeste do Brasil. Trabalhos Oceanográficos da Universidade Federal de Pernambuco 14: 117-130. https://doi.org/10.5914/tropocean.v14i1.2570

Ramos-Porto M., Torres M.F.A. \& Viana G.F.S. 1996. Crustáceos decápodos coletados durante as expedições Nordeste III e Pavasas I (Penaeidea e Caridea). Trabalhos Oceanográficos da Universidade Federal de Pernambuco 24: 211-227. https://doi.org/10.5914/tropocean.v24i1.2709

Ronquist F., Teslenko M., van der Mark P., Ayres D.L., Darling A., Höhna S., Larget B., Liu L., Suchard M.A. \& Huelsenbeck J.P. 2012. MrBayes 3.2: efficient Bayesian phylogenetic inference and model choice across a large model space. Systematic Biology 61: 539-542.

https://doi.org/10.1093/sysbio/sys029

Sambrook J., Fritsch E.F. \& Maniatis T. 1989. Molecular Cloning: A Laboratory Manual. Cold Spring Harbor Laboratory Press, Nova York, USA.

Schubart C.D., Cuesta J.A. \& Felder D.L. 2002. Glyptograpsidae, a new brachyuran family from Central America: larval and adult morphology, and a molecular phylogeny of the Grapsoidea. Journal of Crustacean Biology 22: 28-44. https://doi.org/10.1163/20021975-99990206

Soledade G.O. \& Almeida A.O. 2013. Snapping shrimps of the genus Alpheus Fabricius, 1798 from Brazil (Caridea: Alpheidae): updated checklist and key for identification. Nauplius 21: 89-122.

https://doi.org/10.1590/S0104-64972013000100010

Soledade G.O., Scioli J.A., Terossi M., Mantelatto F.L. \& Almeida A.O. 2019. Congruence between morphology and molecular data supports the distinction between the snapping shrimps Alpheus macrocheles and A. amblyonyx (Caridea, Alpheidae). Zootaxa 4624: 1-22.

https://doi.org/10.11646/zootaxa.4624.1.1

Souza J.A.F., Schwamborn R., Barreto A.V., Farias I.D., Fernandes L.M.G. \& Coelho P.A. 2011. Marine and estuarine shrimps (Dendrobranchiata, Stenopodidea, and Caridea), of Pernambuco state (Brazil) and northeastern Brazilian oceanic islands. Atlântica 33: 33-63. https://doi.org/10.5088/at1.2011.33.1.33

Tamura K., Peterson D., Peterson N., Stecher G., Nei M. \& Kumar S. 2011. MEGA5: Molecular Evolutionary Genetics Analysis using maximum likelihood, evolutionary distance, and maximum parsimony methods. Molecular Biology and Evolution 28: 2731-2739.

https://doi.org/10.1093/molbev/msr121

Udekem d'Acoz C. d' 1999. Inventaire et distribution des crustacés décapodes de l'Atlantique nordoriental, de la Mediterranée et des eaux adjacentes au nord de $25^{\circ} \mathrm{N}$. Patrimoines Naturels 40: 1-393. Muséum nationale d'histoire naturelle, Paris.

Williams S.T., Knowlton N., Weigt L.A. \& Jara J.A. 2001. Evidence for three major clades within the snapping shrimp genus Alpheus inferred from nuclear and mitochondrial gene sequence data. Molecular Phylogenetics and Evolution 20: 375-389. https://doi.org/10.1006/mpev.2001.0976

Manuscript received: 7 August 2019

Manuscript accepted: 10 September 2019 
Published on: 28 November 2019

Topic editor: Rudy Jocqué

Desk editor: Pepe Fernández

Printed versions of all papers are also deposited in the libraries of the institutes that are members of the EJT consortium: Muséum national d'histoire naturelle, Paris, France; Meise Botanic Garden, Belgium; Royal Museum for Central Africa, Tervuren, Belgium; Royal Belgian Institute of Natural Sciences, Brussels, Belgium; Natural History Museum of Denmark, Copenhagen, Denmark; Naturalis Biodiversity Center, Leiden, the Netherlands; Museo Nacional de Ciencias Naturales-CSIC, Madrid, Spain; Real Jardín Botánico de Madrid CSIC, Spain; Zoological Research Museum Alexander Koenig, Bonn, Germany; National Museum, Prague, Czech Republic. 